\title{
Perceptions of Indonesian Politics in the Run-up to the 2009 General Election
}

\author{
Dwi Tiyanto \\ Faculty of Social and Political Science, Sebelas Maret University \\ Jalan Ir. H. Sutami 36 A, Surakarta. \\ Solo 57121. Indonesia \\ Tel: 62-271-716881Ｅ-mail: mail@uns.ac.id \\ Pawito \\ Faculty of Social and Political Science, Sebelas Maret University \\ Jalan Ir. H. Sutami 36 A, Surakarta. \\ Solo 57121. Indonesia \\ Tel: 62-271-716881Ｅ-mail: mail@uns.ac.id \\ Pam Nilan (Corresponding author) \\ School of Humanities and Social Science, University Of Newcastle \\ University Drive, Callaghan \\ NSW 2308. Australia \\ Tel: 61-2-49215912Ｅ-mail: Pamela.Nilan@newcastle.edu.au

\section{Sri Hastjarjo} \\ Faculty of Social and Political Science, Sebelas Maret University \\ Jalan Ir. H. Sutami 36 A, Surakarta. \\ Solo 57121. Indonesia \\ Tel: 62-271-716881Ｅ-mail: mail@uns.ac.id
}

\begin{abstract}
Indonesia has had ten years of constitutional democracy since the end of the Suharto era. In 2009 the country heads again to a national election. In the lead-up period the major parties have been pressing not only to reduce the number of parties eligible to stand, but to create conditions in which a future president can only come from a major party, which is not the situation at present. At the same time, there are almost weekly reports in the Indonesian media of corruption allegations and charges against both local and national politicians. This paper considers survey and interview data on the opinions of members of the general public in Central Java about the performance of political parties and the political elite in the run-up to the 2009 election. Selected newspaper coverage of political corruption cases is also considered.
\end{abstract}

Keywords: Indonesia, Politics, General public, Media, 2009 election.

\section{The current political climate in Indonesia}

\subsection{The state of play}

According to the General Electoral Commission (Komisi Pemilihan Umum - KPU), as of July 2008, 34 political parties are registered and will contest the 2009 Indonesian parliamentary and presidential elections. 16 of these parties are well-established and gained a significant proportion of votes in the 2004 elections. They will undoubtably be major players in the 2009 general election for seats in the DPR (House of Representatives). The eight most important are: secular-nationalist PDI-P (Indonesian Democratic Party of Struggle): Suharto's secular party Golkar (now enjoying 
new popularity); traditional Muslim party $P K B$ (National Awakening Party); moderate Muslim party PPP (United Development Party); modernist Muslim party PAN (National Mandate Party); puritan Islamic party PKS (Prosperous Justice Party); ultra-modernist Islamic party $P B B$ (Moon and Crescent Party); and current president Susilo Bambang Yudhoyono's $P D$ (Democratic Party). Of these eight - two facts should be noted. Firstly, the presence of five Muslim parties in the top eight has the effect of 'splitting' the pro-Muslim vote across the country, especially since there are a number of smaller Muslim parties among the total of 34 parties registered. Secondly, the real power struggle is between PDI-P (popularly symbolised in the figure of Megawati Soekarnoputri), Golkar (currently symbolised by popular Vice-President Jusuf Kalla), and $P K B$ (popularly symbolised in the figure of Abdurrahman Wahid known as Gus Dur). These three figures (and current president Susilo Bambang Yudhoyono) are regularly satirised and savaged on Indonesian television in programs like Republik Mimpi:

Indonesian political parties are the target of fierce criticism by observers, civil society leaders and the general public. Opinion surveys show that Indonesians view the parties as corrupt, unresponsive, self-absorbed and ineffective. Newspaper columns regularly launch stinging attacks on party leaders, and NGOs have focused many of their programs on scrutinising party activities - or the lack thereof (Mietzner, 2008).

However as Mietzner points out, most media criticism comes from a populist perspective and fails to address analytically the problem of party activism. For example, Indonesia's dysfunctional system of party financing leads directly to the option of raising funds from wealthy patrons and power brokers.

\subsection{The strengthening of political hegemony}

During 2007-2008, Golkar and PDI-P have been attempting to strengthen their hegemony. 'Hegemony' comes from the Greek root egemon - leader or ruler. In Gramsci's work, hegemony refers to cultural leadership through which the dominated come to consent to their own domination by an elite. Gramsci's use of hegemony cannot be understood apart from his ideas about the state and civil society (Gramsci, 1971, p. 446), and neither can political party hegemony in Indonesia be understood separately from the Indonesian state. Gramsci considers Marxian superstructure at two levels 'civil society' (including families, churches, trade unions, schools) and 'political society' (the State). He demonstrates how civil society establishes and organises social interaction and consciousness in highly political ways so that domination by the state-supported political elite is achieved by consent (social hegemony). Gramsci brings 'social hegemony' and 'political government' together in the 'integral State' (p. 267), describing a complex web of practical and theoretical activities through which the elite not only justifies and maintains dominance, but wins the active consent of the subordinated.

In Indonesia, as Mietzner (2008) points out; 'most Indonesian parties are still rooted in distinct social, religious or ideological milieus, and the majority of voters feel reluctant to move between those constituencies. These entrenched divisions in Indonesian society have obstructed the internal modernisation of the mainstream parties, but have also been responsible for their survival', since people continue to loyally vote for the parties they have traditionally supported even though they may not believe the promises of party politicans nor endorse their actions. The relative success of PDI-P and Golkar candidates in local elections across the country in the past three years have given the two big parties confidence that they can build upon their existing dominance of the national parliament.

Not only have the two traditional rival parties seriously considered a coalition, which would ensure their absolute control of parliament, they have dominated parliamentary debates dealing with electoral regulation reform. For example, Golkar and PDI-P held joint meetings in Medan on 20 June 2007, and in Palembang on 24 July 2007, to discuss a package of draft political laws (Paket RUU Politik),

The proposed laws cover electoral thresholds; electoral districts and district size; party financing and campaign financing; and voting rights for armed forces personnel. The two large parties are arguing for an increase in the current electoral threshold for parties to run in the general election from 3\% of seats in the DPR to at least 5\% (Baswedan, 2007, p. 330).

A further proposed law is that for each pair of presidential and deputy presidential candidates, their party must have at least 30 per cent of DPR seats, or 30 per cent of the vote - on the grounds that a president needs strong parliamentary support (Baswedan, 2007, p. 331). Certainly President Yudhoyono has struggled at times because his party won only 8 per cent of the 2004 vote and controls only 10 per cent of DPR seats (Baswedan, 2007, p. 324). However, there is general suspicion of the new electoral regulations because they are felt to discriminate heavily against non-mainstream and small political parties in the fielding of candidates. That is, they threaten the spirit of democracy.

As indicated above, the two parties have poured not only energy but billions of rupiah into campaigning for regional and local elections, to the extent that there have been few independent or small party candidates running for office. Candidates must now be nominated by a single political party or a coalition of political parties. So Poppy Darsono - a former photographic model - was not allowed to run independently for governor in the 2008 election in Central Java Province. However, it should be noted that the trend against independent candidates is partly an outcome of the 
constitution. Indonesian law forces political parties to establish themselves nationwide, even to the sub-district level. This broad and deep network operates to strengthen the authority of the major parties and offers significant obstacles for new parties to be viably created (Mietzner, 2008), or for independent candidates to gain endorsement.

\subsection{Looking towards the 2009 election}

It can be argued that recent attempts by the major parties to strengthen their hegemony will have a significant impact on the 2009 elections, both for the parliament and for the presidency. Currently, such attempts tend to reinforce the notion in the public mind that the main agenda of the major electoral players is not only winning on the day, but shoring up their respective power bases. We propose that these recent strategies of domination by major political parties have brought to the surface the dissatisfaction and lack of trust of ordinary Indonesian citizens in the democratic political process. Although the Indonesian people may show strong local loyalties in voting, in essence they do not trust party politics or the political elite, especially the political elite from parties well-established in the DPR (House of Representatives) or the DPRD (Provincial Legislative Council or City Council). In the eyes of ordinary citizens, political parties and members of political elites give the impression of working hard in pursuit of their own ambitions, rather than looking after the interests of their constituencies. Marbawi $(2007$, p. 17) argues that there is danger in the neglectful regimes of political parties because the threat of civil violence increases. The widespread belief that there is corruption in political circles further undermines the popularity of political parties and increases the likelihood of civil unrest. Mass public frustration, as Marbawi reminds us, can become a serious threat to democracy and to political parties themselves. Evidence of this trend in public response to political corruption and ineffectiveness is shown by frequent wide-ranging protest action and demonstrations about a number of economic and social issues.

\section{Research questions and methodology}

Given the current political climate as described above, it is productive to examine what ordinary Indonesians think about the actions by political parties and by members of the political elite in the run-up to the 2009 general election. An opinion poll by Kompas found that of 837 respondents, 79 per cent agreed that political party orientation was more towards power than towards people's interests. 71.3 per cent thought the political recruitment process was unsatisfactory, and 73.1 per cent thought political parties were marred by internal conflicts and splits among the elite (Sultani, 2007, p. 5 ). We seek to explore these ideas further in this paper.

\subsection{Research questions}

Our study posed three main questions:

What do members of the general public think about the performance of political parties and political elites in the run-up to the 2009 general election?

Do social-demographic factors such as level of education, family income, sex, and age affect the way people think about the performance of political parties and the performance of political elites?

How are the mass media, especially the print media, representing political parties and political elites during this period?

\subsection{Methodology}

The study employed a multi-method strategy consisting of a survey, in-depth interviews, and textual analysis of newspaper reports. The survey was conducted in 2008 in Solo, Central Java, with 180 adult respondents. The survey asked: (a) for social and demographic details of respondents; (b) what the respondents thought of the performance of political parties; and (c) what respondents thought of the performance of political elites. The survey data was subject to a descriptive analysis of frequencies. Correlations were tested using Pearson's correlation coefficient. 15 interviews were conducted with people from a variety of social backgrounds including: garbage collector (pemulung); street singers/beggars (pengamen); small-scale business-owners; and university students. Interviewees were asked about their views on the performance of political parties and political elites. Finally, political news reports in the following media sources were subject to a textual analysis: Kompas, Jawa Pos and Republika daily newspapers; and Tempo weekly news magazine.

\section{Survey findings}

\subsection{Correlations}

The survey data was first analysed using calculations of Pearson's coefficient to establish whether there was any correlation between social and demographic variables and responses. The following table summarises the results of this analysis (two-tailed).

Insert Table 1 here.

The two variables which show a significant correlation with both political party performance appraisal and political elite performance appraisal, are family income, and level of education. For the family income variable, there was a significant difference between respondents with a high family income and those with a low family income. Respondents 
who reported a high family income tended to have a low opinion of both political party performance and the performance of the political elite. Similarly, respondents who reported a high level of education did not rank the performance of political parties and political elites highly.

\subsection{Performance of political parties}

Survey questions asked about the performance of political parties according to the following functions: (a) aggregating and articulating the aspirations of the people; (b) leadership recruitment; (c) formation of government; (d) political identity; (e) mass mobilization; (f) social integration.

Insert Table 2 here.

Table 2 shows that over half the respondents were dissatisfied with the performance of political parties in three key areas: aggregating and articulating the aspirations of the people (66.7\%); leadership recruitment (51.1\%); and social integration (56.1\%). Respondents were less dissatisfied with political party performance in the areas of political identity and mass mobilization. Significantly, the highest level of dissatisfaction - two-thirds of respondents - was with the extent to which political parties took account of the wishes of their constituents and represented these in the public domain and the sites of government. We might infer from this that at present Indonesian political parties are not perceived as adequately fulfilling the demands of the citizenry to address their interests.

\subsection{Performance of the political elite}

To explore views about the performance of the political elite (senior elected decision-makers), respondents were asked about four aspects of their performance: (a) whether the political elite engaged closely with the people; (b) whether the political elite made a serious attempt to strive for what people wanted; (c) whether the political elite demonstrated dedication to serving the public interest; and (d) the orientation of the political elite to the use of power.

Insert Table 3 here.

In summary, less than a quarter of respondents were satisfied with the performance of the political elite. The highest scores for dissatisfaction were in respect to power orientation, and the issue of having a close relationship with the people.

\section{Interview data findings}

\subsection{Performance of political parties}

Data from the in-depth interviews tended to confirm public dissatisfaction with the performance of political parties, for example:

It seems to me that the performance of political parties is unsatisfactory. Many people suffer from malnutrition, they have very limited access to education and jobs. Who is in the wrong? They [political parties] do not represent the demands of the people (Tumin, male, 48, garbage collector).

Tumin added that he thought Indonesian political parties ignored wong cilik (Javanese: people of low social status). Many comments were made about price increases, for example,

Political parties do not perform in an optimal way to address what people want. Increases in the price of goods, especially fuels, have made people suffer a lot recently (Lusi, female, 44, teacher).

It was also often claimed that people were compelled to articulate their demands by organizing and/or joining protest movements, for example,

So far the performance of political parties has been much less than optimal and because of this people use protest movements to articulate their aspirations. Political parties make very few attempts to get close to their constituents. They only do it during the period of the election campaign (Anti, female, 22, university student).

\subsection{Performances of political elites}

Interview data confirmed the dissatisfaction of the general public with the performance of the political elite. This frustration was not just with the elected representatives of the two big secular parties, but with Muslim politicans also, for example,

It is very clear that they [political elites] are primarily oriented to power even though they may come from religious [Muslim] groups (Lusi, female, 44, teacher).

It was claimed that members of the political elite run for election to get power and to maintain power rather than dedicating themselves to striving for the demands of the people, for example:

They think only power, power, power. They work much more for their own interests than for the interests of the people. So it is meaningless what they have done so far, whether we are talking about political parties or the political elite. They simply perform badly and so they disappoint the public (Tumin, male, 48, garbage collector. 
There were some inferences of nepotism, for instance:

It is far from satisfactory. The Indonesian political elite mostly works for personal interests, including the interests of family and allies, not for the interests of the people (Sardiyo, male, 36, policeman).

There were also some more analytical critical views expressed.

Yes. Politics means power. In Indonesia the political elites performed poorly for a long time, representing only a narrow range of perspectives and interests. So look what's happened now. The interests of the people and the nation are still marginalized by the interests of the political elite - personal interests as well as crony interests. Conflicts of interest therefore often escalate and involve those from many different disenfranchised groups (Sardi, male, 25, junior university lecturer).

Sardi indicates that even though politics is usually understood as an inevitable struggle for power, the Indonesian political elite of the New Order (the Suharto regime) manipulated power unfairly. He inmplies that even now, after democratic reform, the political elite still seems to care little either for the demands of the people or for dealing with the problems of the nation. He points to clashes of interest between the political elite and a range of lobby groups, which spills over into demonstrations and civil unrest.

It was claimed that the interests of the political party itself were inevitably defended over the interests of the people, for example:

Members of the political elite are put there by their political parties. However, members of the political elite that often criticize the system fall out of favour with the party leaders. So the demands of the people are subsequently marginalized. It is easier for members of the political elite to work for their own interests than to work for the interests of the people (Lusi, female, 27, teacher).

Lusi maintains that members of the political elite are implicity encouraged to work primarily for the interest of the political parties they come from rather than for the interests of the people they represent. She makes a further useful point. It may be true that there is less provocation in politicians working for their own personal interests than in criticising the status quo, as far as party power-brokers intent on their own ambitions are concerned.

\section{Media analysis findings}

The third research question for this study asked how the performance of Indonesian political parties and the political elite is being represented by the mass media in the run-up to the 2009 election. To this end, national newspapers Kompas and Republika, and regional newspaper Jawa Pos were analysed, as well as Tempo - a national news magazine. Overall, our textual analysis indicates that political parties and the political elite were invariably represented in a negative way. The negative focus was usually on: (a) the dominant role of the major political parties in pushing for new regulations; (b) internal party dissent; and (c) allegations of corruption against specific political parties and/or members of the political elite.

\subsection{Party domination and new regulations}

Domination by the two major political parties - Golkar and PDI-P - was a key theme in news media articles pertaining to elections, whether local government elections or the forthcoming 2009 legislative and presidential election. For example, a news item in the Jawa Pos (14 November 2007, p. 2) titled Ambisi Golkar-PDI-P Terus Dilawan (ambitions of Golkar-PDI-P continue to be opposed) explained how a group of smaller parties in the DPR fought against the joint suggestion by Golkar and PDI-P to decrease DPR seat allocation in electoral districts from 3-12 seats to 3-6 seats - a move which would have increased seats for the major parties and decreased electoral opportunities for minor parties. The article quoted the head of the PBR (Partai Bintang Reformasi - a minor Muslim party) as saying that a decrease of DPR seat allocations for electoral districts would eliminate opportunities for small parties and newly established parties to get seats. He argued that this opportunity should be a guaranteed democratic right of formally recognised political parties. Most of the smaller parties expressed agreement with the PBR position.

In another example, on Friday 14 March 2008, a Kompas opinion piece (p. 5) proclaimed Paket UU Politik Langkah Hegemoni Parpol Besar (package of political laws: further steps towards major party hegemony). The leftist writer condemned attempts by the major parties to 'simplify' the party system because what they were really proposing were tactics to maintain parliamentary and local government domination. He argued that most of the arguments for 'simplification' of the electoral process returned to the idea that a strong parliament and a strong president in 2009 would need majority support in the DPR. However, such a move, he argued, would come at a cost to true democracy. Not only would smaller parties vanish, but large-scale party coalitions would be empowered to take even less notice of the demands of the people.

Republika newspaper belongs to the opposite political camp to Kompas and usually takes a right-wing view, yet it too has been reporting on the hegemonic practices of the major parties. In the 26 October 2007 issue (p. 3), a news item was headed SBY Dicoba Diganjal dengan Syarat Dukungan Capres (an attempt to block SBY [Susilo Bambang Yudoyono] through the proposed president's party support law). Golkar members of the DPR suggested a pre-requisite minimum 
30-35 per cent legislative voter support for the party of any candidate to nominate to run for president. This law would in theory prevent incumbent president Susilo Bambang Yudoyono (SBY) from being nominated as a presidential candidate because his PD party gained fewer seats than this. Such a move can be interpreted as yet another example of attempts by the major parties to strengthen their hegemony.

\subsection{Internal party conflicts}

The 2007-2008 period was characterised by troubles between President SBY (from minority party PD) and Vice-President Jusuf Kalla (Golkar), and by internal party conflicts. The mass media paid much attention to these disputes, emphasising many other quarrels and scandals in parties such as PBR, PKB and PDI-P.

A notable example in Kompas was the extensively-reported conflict in the political elite of PKB in 2008. PKB is the party linked to Nahdlatul Ulama - the largest Muslim organisation in Indonesia with a vast support base in Java. Former Indonesian president and party founder Abdurrahman Wahid (Gus Dur) fell out with his nephew Muhaimin Iskandar (Cak Imin), the head of Dewan Tanfidz (the PKB Executive Council). At a stacked plenary meeting of PKB on 27 March, Muhaimin was asked to step down - Muhaimin Iskandar Diminta Mundur (Kompas 2008, 28 March, p. 15). The issue seems to have been one of disloyalty to Gus Dur himself. However, Muhaimin refused to step down, instead filing a lawsuit against Gus Dur and his faction of the PKB. The Indonesian Supreme Court ruled in July 2008 that Muhaimin should be party chairman while Gus Dur should remain as the party patron only. Gus Dur has publicly condemned the decision and the factional split has not been healed. While official PKB press releases put a positive spin on the outcome, it is widely acknowledged that this factional conflict threatens the electoral performance of the PKB in the 2009 general election. In early September 2008, it was reported that Gus Dur had instructed PKB supporters loyal to him to picket election commission offices across the country, a move he said would deter the KPU from recognizing Muhaimin's faction as the official representative of the PKB (The Jakarta Post, September 9, 2008). The fallout from this internal rivalry may result in a significant fall in support for PKB from the mass of Javanese traditionally loyal to Nahdlatul Ulama.

\subsection{Allegations of corruption}

The Indonesian press regularly reports allegations and findings of corruption against elected members of government both local and national. It could be widely assumed that there are few if any members of the political elite who are not engaged in some form of corruption, because of the frequency with which such reports appear. Taking the month of April 2008, for example, every form of print media in the country reported that PPP (Partai Persatuan PembangunanUnited Development Party) national politician Al Amin Nur Nasution had been arrested while bribing a Riau government official - Azirwan - at the Ritz Carlton in Jakarta. Tempo in July pointed out that Nasution stood to gain from the removal of protected forest status in Riau for urban development. He was also accused of sexual misconduct. Nasution was subsequently expelled from the PPP. On 10 April 2008, it was widely reported in the news media that former Bank Indonesia governor Burhanuddin Abdullah had been formally charged with bribing a number of politicians, involving the misappropriation of over 100 billion rupiah from bank deposits. Earlier, on the 4 April 2008, Kompas had reported that two local politicians in Jember had been charged with misappropriating 450 million rupiah from legal aid funds and 726 million rupiah from local parliament funds intended for civic works.

Since April 2008, charges against politicians of bribery, corruption and sexual misconduct have continued. Of recent note was the widely-reported July 2008 arrest of PBR politician Bulyan Royan - caught red-handed taking a bribe from businessman Dedi Suwarsono. In a lead article Kompas (2 July 2008, p. 5) reported that other DPR politicians were also implicated. The lawyer for Suwarsono stated that the billions of rupiah Royan handed over in a North Jakarta Hotel were for the procurement of ocean patrol boats by the Ministry of Transport. Royan stood to gain financially from the tender. The most recent reported corruption case involves President Yudhoyono himself. He stand accused of protecting one of his senior advisors - Heru Lelono - who was apparently behind a 'miraculous' hybrid rice crop scandal (Fitzpatrick 2008a).

These examples are only the tip of the iceberg. It was recently claimed in English-language newspaper The Jakarta Post on 30 August 2008 that 'data from Indonesia Corruption Watch (ICW) earlier revealed at least 35 lawmakers - 15 from PDI-P, eight from Golkar, eight from PPP, three from PD, three from PAN and one from PKS - who had allegedly been involved in corruption'. Meitzner reports that 'more than 1000 local legislators, almost ten per cent of the total number of parliamentarians across Indonesia, have been investigated for corruption since 2004' (2008). There are weeks in which Indonesian national newspapers, and radio and television news broadcasts are literally crammed with stories of political corruption. It seems obvious that this has an effect on the way members of the general public view political parties and politicians.

\section{Discussion}

\subsection{Past practice}

We detect two contradictory discourses in current general public attitudes to politics which may help illuminate the mystery of Indonesian voters' 'love-hate relationship with their political parties' (Mietzner, 2008). For despite their 
frustration, Indonesians usually turn out to vote in large numbers,

In 1999 and 2004, participation in national elections ranged between 75 and 93 percent, a rate that even consolidated democracies would consider healthy. Even in direct elections for local government heads, where the role of the parties is weaker, an average of 69 percent of registered voters took part in the ballots (Mietzner, 2008).

Foreshadowing our identification of the two principle voter discourses that lie behind such apparent loyalty to the process of voting, Vickers (2007, p. 222) speaks of 'post-Suharto Indonesia's combination of optimistic reformism and cynical fatigue'.

\subsection{Cynical fatigue vs 'bread and circuses'}

The first voter discourse: - wary disbelief, enshrines a deep conviction that whatever formal political process may be about, it is almost never about representing the interests of the people. This corresponds to Vickers' term - 'cynical fatigue'. During the New Order period, citizens voted under pressure for one of only three tightly-controlled parties and there was never any doubt that Golkar would win. Studies by Hainsworth et al. (2007) and Hill (1996), for example, reveal how the New Order government literally bought loyalty and legitimation, bludgeoning any opposition or independent movement into an underground existence. Elections were manipulated. Votes were sometimes rewarded by local infrastructure improvements in education, health, and farming, but often not. The New Order government achieved domination with the support of military; through the hegemonic political party Golkar; and through oil export income.

Yet at the same time, during the New Order election campaigns (and even now), there was a great air of festivity during elections, involving colour, music, rallies, parades, fanfare and small gifts. The term 'bread and circuses' comes originally from the Romans. Commentators in ancient times were frustrated to find that rather than sticking to civic principles, voters followed whichever political leaders offered food and entertainment - 'bread and circuses' - during election campaigns. The 'bread and circuses' strategy appears to have flourished in Indonesian politics. For example, election campaigns used to rely (and still do to some extent) on popular artis dangdut (indigenous rock music singers/dancers) travelling to even the smallest villages on the campaign trail (Fitzpatrick, 2008b, p. 16). The musical theme of Indonesian election campaigns was taken further when (male) politicians started singing as part of their election campaigns in 1999, and this reached its height in the 2004 election with several candidates, including current president SBY, releasing albums. This history of general election festivity and entertainment is productive for understanding why Indonesian voters regularly turn out, despite their conviction that there will be little for them in the long run. Far from trivial, political party-sponsored festivities and entertainment during election campaigns illuminate the workings of political hegemony. As Gramsci's theories imply (see section 1.2 above) hegemony operates through the targeted organisation of the social interaction and consciousness of the people. Party-sponsored election festivities and entertainment - even singing politicians - constitute an effort to convince local people that the party in question can and will please them. Such apparently light-hearted events are attempts to win the active consent of the subordinated in Gramsci's terms.

Yet while local voters might be happy to be wooed by 'bread and circuses' on the party election campaign trail, that does not mean they really expect anything to change once politicians are voted in. As we saw in the interview data excerpts above, when unemployment, malnutrition and rising prices are mentioned, there is sense of fatalism in the way these are discussed. Although it might reasonably be expected that political parties should try resolve these problems, there seems to be a sense of weary certainty that they will not. As Sultani $(2006$, p. 4) states in his commentary on the performance of the DPR, 'low commitment to nation; giving in to pressure; decline of moral integrity - make the pace of change tedious in the eyes of public', even despite the recruitment of young, and better-educated DPR members over the past ten years.

The discourse of 'cynical fatigue' is fuelled by daily political reports in the mass media such as those we discuss above. If readers and viewers only hear about politicians in relation to scandal, corruption and in-fighting, and rarely about politicians trying to meet the needs of their constituencies, then it should not be surprising that of 837 respondents in the Kompas poll over 70 per cent were dissatisfied and disillusioned (Sultani, 2007, p. 5). It should be noted that Kompas readers tend to be middle-class and well-educated. Kompas offers a more sophisticated and detailed analysis of the current political landscape than the populist media, and this perhaps gives a clue as to why there was a correlation in our survey data indicating that the higher the income and education of respondents, the lower their opinions of political parties and the political elite.

\subsection{Loyalty and hope}

The second important voter discourse is one of entwined loyalty and hope. This discourse emerged strongly after 1998, although its roots probably lie in the revolutionary birth of the Indonesian nation. Despite the pattern of poor performance by political parties and politicians, Indonesian voters continue to be on the whole loyal and optimistic. Optimism was at its height during the 1999 election campaign when democracy flourished for the first time. 48 political 
parties were able to contest seats and the military took a neutral role. However, not everyone was satisfied with the 1999 election outcome. For example, most voters did not grasp how the president was elected according to the constitution of the time, and while Megawati Soerkanoputri's PDI-P won the election, she did not become president. Disappointment led to widespread riots.

Subsequently, as democratic optimism in the post-reform era declined, Indonesian political parties lost focus, and lost the confidence of voters. By early 2006, Indonesian political parties had an even worse performance record. Internal dissent and corruption encouraged an exceptionally negative view of politicians and of party politics (Sultani, 2006, p. 5). Yet as Mietzner (2008) points out, people still turn up to vote in relatively high numbers, and in doing so demonstrate their loyalty to specific social, cultural, religious and/or ideological symbols and constituencies, articulating a strong sense of the continuity of family and communal voting practices over time. In yet another sense, voting signifies an act of hope. In the comments of interviewees above for example, there is an implied sense of outrage that their hopes and expectations have not been met, rather than a lack of hope.

The discourse of loyalty and hope is also fuelled by political reports in the media. As well as news items on political scandals and in-fighting, Indonesian newspapers and television broadcasters cover the campaign trail of local government candidates and party leaders as well. So, for example, when Vice-President and Golkar leader Jusuf Kalla visits his place of origin - Sulawesi - local media sources report his visit very positively, stressing Kalla's commitment to the people of Sulawesi. And of course, politicians talk up for reporters the importance of their own regions and ethnic/cultural constituencies when they are campaigning 'at home'. Megawati Soekarnoputri is expert at this, drawing heavily upon the sentimental legacy of her father - President Soerkarno - when she campaigns in Central Java and Bali. The political courting of local loyalties signifies once again how hegemony operates through the targeted organisation of the social interaction and consciousness of the people, in this case the history and tradition of ethnic and geographical solidarity. The appeal of political parties to forms of local primordialism represents yet another example of attempts to secure the active consent of the subordinated.

\subsubsection{Fear}

Loyalty and hope are also fuelled by fear. Certainly a great deal has changed in Indonesian politics since 1998. Democratic reforms have resulted in a free media and free and open elections at every level, including local government. Regional autonomy legislation has seen much greater political control move to local constituencies. The president is now elected by the people. The press has much greater freedom to report on news, and there has been an extraordinary increase in the amount of news reported (Pawito, 2002). This relative freedom and expansion is often interpreted as proof of democracy. Yet the current processes of Indonesian democracy have long been falling well short of peoples' expectations, and the threat of local or mass political violence was constant in the post-Suharto years (Vickers, 2007, p. 213), at least until 2004.

At present, the Indonesian economy is growing strongly and the poverty rate is falling (The Jakarta Post, August 26, 2008). Yet these gains could be swiftly brushed aside if the country descended once again into civil unrest due to political anger and frustration. In their slogans and campaigns, all eight significant political parties, whether secular or Muslim, promise not only 'clean' government, but civil stability and continued economic growth. Politicians routinely make press statements to this effect which perhaps build a sense of hope for the public even while they might feel it is unwise to trust such promises. Perhaps many want to believe political promises of civil stability because they fear the alternative of increasing civil violence.

\subsection{Media reports: A challenge to hegemony?}

It should be noted that the active consent of the subordinated (the masses) to the political hegemony of dominant Indonesian political parties could be challenged by relevations of greed and corruption in the mass media. For example, ordinary citizens understandably experience disappointment and anxiety when they read about the apparently honest representatives of their chosen party becoming DPR members who go on to become corrupt intermediaries passing non-transparent budgets through parliament that benefit local government officers. It must have been particularly galling for loyal supporters of some parties to read that the politicians they helped elect have even gone so far as to appropriate funds intended for natural disaster prevention and relief.

The question we must ask however, is whether press revelations of political corruption do in themselves challenge the political hegemony of the major parties, or whether such media reports actually encourage apathy and cynicism, leading to widespread voter disaffection which implicitly strengthens the hegemony of the dominant political players.

\subsection{Golput}

Given the arguments presented in this paper we might well anticipate that if 'cynical fatigue' wins out over loyalty and hope for the voting public we will see a much higher rate of golput (lack of a formal vote: either no vote or a 'donkey' vote) in the 2009 general elections than in previous elections. Sujatmiko (2007) maintains that the development of a fully-fuctioning democracy in Indonesia is hampered by lack of political accountability and increasing distance between 
political process and the citizenry. There is still a lack of transparency at all levels of the legislature. The general public has little opportunity to participate in debate over the formation of public policies, through a referendum for instance. When people feel deeply disappointed, or disconnected, they either do not vote, or they may disfigure the voting form. The rate of golput has been high in some recent local elections. For example, in the 2008 election for the Governor of Central Java 41.5 per cent of registered voters golput (Kompas, 10 April 2008, p. 1).

In post-reformasi Indonesian elections there are almost always protests and riots afterwards because supporters of defeated candidates are not satisfied, and accusations of misconduct fly. Sugiarto $(2005$, p. 6) maintains that one cause of ubiquitous post-election demonstrations in Indonesia is lack of public trust in the actual electoral process, especially the nomination and funding of party candidates, and the counting of votes. Local government election organizers are frequently regarded as unreliable, and there is lack of trust in local law enforcement. Disappointed and angry voters may choose not to vote again in any election, believing that there will be no integrity at all in the formal process of constitutional democracy. If this turns out to be the case for the 2009 general election, we can expect to see the rate of golput escalate.

\section{Conclusion}

From the data assembled in this paper we may safely assume that the Indonesian public in general does not hold political parties and political elites in high esteem. Table 1 indicates that according to our survey results dissatisfaction is more marked for those with a higher income and better education. The frequency tables indicate that three-quarters of 180 respondents were dissatisfied in various ways with the performance of political parties and the political elites. This finding was confirmed in the interviews. Realizing the aspirations of the people, social integration, and leader recruitment, were the areas in which political parties caused disappointment. On the performance of political elites repondents were most dissatisfied with their grabs for power (lobbying for self-serving electoral change, doing shady deals with opposition parties, graft, corruption and nepotism); and the distance between political elites and the people. In short, it seems to be widely understood that most politicians are inherently self-serving, greedy, ruthless and amoral.

We argued above in sections 5 and 6.2 above that the dissatisfaction of the general public is fuelled by the negative mass media representation of political parties and political elites, as our selected print media examples demonstrate. The major negative discourses of this media representation were found to be: (a) the tendency of major political parties to defend their power base at any cost; (b) internal conflicts of parties and factionalism; and (c) allegations and charges of corruption and scandal against politicians and party officials.

So what kind of picture emerges here in the run-up to the 2009 election? The data assembled in the paper indicate that a generally negative view of politicians and political parties is held by both the mass media and the general public. Although it appears that a more analytically critical and intellectual perspective is generated by the middle class, and by newspapers such as Kompas that inform the opinions of better-educated people, in Java ordinary people -wong cilik also feel disillusioned and disappointed. In one direction this indicates increasing cynicism and apathy, which are likely to translate into a high rate of golput in the 2009 election. In the other direction, the disillusionment of the masses with the major parties and the political elite opens the way for minor political parties running a strong anti-corruption hard line, such as the Islamist PKS party, to gain widespread appeal. Perhaps the deepest and most serious outcome though, could be widespread mistrust of the political process of democracy itself. If the Indonesian public feel that their trust in constitutional democracy for the nation has been betrayed in the rush by the major parties for greater political hegemony, then they are likely to express that rage and frustration in protest actions and demonstrations that may escalate into mass civil unrest, threatening the economic and social gains of the past ten years.

\section{References}

Baswedan, A. (2007). The presidency, local elections and the future of democracy. Bulletin of Indonesian Economic Studies, 43(3), 323-340.

Fitzpatrick, S. (2008a). SBY comes a cropper over hybrid rice scandal. The Australian, September 11, [Online] Available: http://www.theaustralian.news.com (accessed September 11, 2008).

Fitzpatrick, S. (2008b). Indonesian democracy has to face the music. The Australian, August 31, 16.

\section{Gramsci, A. (1971). Selections from the prison notebooks. London: Lawrence \& Wishart.}

Hainsworth, G., Turner, S. \& Webster, D. (2007). Introduction: Indonesia's democratic struggle: reformasi, otonomi and partisipasi. Asia Pacific Viewpoint, 48(1), 41-46.

Hill, H. (1996). The Indonesian economy since 1966: Southeast Asia's emerging giant. Cambridge: Cambridge University Press.

Marbawi, (2007). Pilkada DKI Jakarta, kuatnya rezim partai. Media Indonesia June 11. [Online] Available: http://mediaindonesia.com (accessed April 10, 2008). 
Mietzner, M. (2008). Stable but unpopular: Indonesians have a love-hate relationship with their political parties. Inside Indonesia, 92 April-June. http://insideindonesia.org/content/view/1068/47/ (Accessed August 20, 2008).

Pawito. (2002). Mass media and democracy: a study of the roles of the mass media in the Indonesian transition period 1997-1999. Unpublished Ph.D Thesis, University of Newcastle, Australia.

Sudjatmiko, I. G., (2007). Political transformation in Post-Suharto Indonesia. Paper presented to the 8th Conference of the Asia Pacific Sociological Association, November 19-21, 2007 Penang, Malaysia.

Sugiarto, T., (2005). Pilkada dan introspeksi parpol. Kompas, August 2, 2005.

Sultani, (2006). Kiprah wakil rakyat yang menjemukan. Kompas, May 2, 2006.

Sultani, (2007). Wajah kusam partai politik. Kompas, January 9, 2007.

Vickers, A. (2005). A history of modern Indonesia. Melbourne: Cambridge University Press.

\section{Media Sources}

Jawa Pos, 2 December 2006.

Jawa Pos, 9 January 2007.

Jawa Pos, 14 November 2007.

Jawa Pos, 28 March 2008.

Jawa Pos, 10 April 2008.

Kompas, 10 September 2007.

Kompas, 14 March 2008.

Kompas, 28 March 2008.

Kompas, 2 July 2008.

Kompas, 4 April 2008.

Kompas, 10 April 2008.

Republika, 26 October 2007.

Tempo, No. 21, Vol. XXXVI, 16-22 July 2007.

The Jakarta Post, 30 August 2008 http://thejakartapost.com

The Jakarta Post, 9 September 2008 http://thejakartapost.com

Table 1. Correlation between socio-demographic variables and responses $\mathrm{N}=180$

\begin{tabular}{lcc}
\hline Variable & $\begin{array}{l}\text { View of political party } \\
\text { performance }\end{array}$ & $\begin{array}{l}\text { View of political elite } \\
\text { performance }\end{array}$ \\
\hline Sex & -0.115 & -0.067 \\
& $(0.124)$ & $(0.374)$ \\
\hline Occupation & 0.135 & -0.042 \\
& $(0.071)$ & $(0.573)$ \\
\hline Age & -0.046 & 0.075 \\
& $(0.541)$ & $(0.371)$ \\
\hline Family income & $-0.250 * *$ & $-0.187 *$ \\
& $(0.001)$ & $(0.012)$ \\
\hline Level & $-0.271 * *$ & $-0.262 * *$ \\
education & $(0.000)$ & $(0.000)$ \\
\hline
\end{tabular}

Note:

* Significant at 0.05

** Significant at 0.01 
Table 2. Responses on the performance of political parties $\mathrm{N}=180$

\begin{tabular}{llll}
\hline Political Function & Responses & Freq & $\%$ \\
\hline 1. Aggregating and articulating & Satisfied & 20 & 11.1 \\
the aspirations of the people & Neutral & 40 & 22.2 \\
& Dissatisfied & 120 & 66.7 \\
\hline 2. Leadership recruitment & Satisfied & 23 & 12.8 \\
& Neutral & 65 & 36.1 \\
& Dissatisfied & 92 & 51.1 \\
\hline 3. Formation of government & Satisfied & 27 & 15 \\
& Neutral & 74 & 41.1 \\
& Dissatisfied & 79 & 43.9 \\
\hline 4. Political identity & Satisfied & 48 & 26.7 \\
& Neutral & 81 & 45 \\
& Dissatisfied & 51 & 28.3 \\
\hline 5. Mass mobilization & Satisfied & 51 & 28.3 \\
& Neutral & 79 & 43.9 \\
& Dissatisfied & 50 & 27.8 \\
\hline 6. Social integration & Satisfied & 35 & 19.4 \\
& Neutral & 44 & 24.4 \\
& Dissatisfied & 101 & 56.1 \\
\hline
\end{tabular}

Table 3. Responses on the performance of the political elite $\mathrm{N}=180$

\begin{tabular}{|c|c|c|c|}
\hline Aspect of Performance & Responses & Freq & $\%$ \\
\hline \multirow{3}{*}{$\begin{array}{l}\text { 1. Has a close relationship with } \\
\text { the people }\end{array}$} & Satisfied & 19 & 10.6 \\
\hline & Neutral & 71 & 39.4 \\
\hline & Dissatisfied & 90 & 50 \\
\hline \multirow{3}{*}{$\begin{array}{l}\text { 2. Strives to meet the demands } \\
\text { of the people }\end{array}$} & Satisfied & 22 & 12.3 \\
\hline & Neutral & 98 & 54.4 \\
\hline & Dissatisfied & 60 & 33.3 \\
\hline \multirow{3}{*}{$\begin{array}{l}\text { 3. Demonstrates dedication to } \\
\text { serving the public interest }\end{array}$} & Satisfied & 35 & 19.4 \\
\hline & Neutral & 97 & 53.9 \\
\hline & Dissatisfied & 48 & 26.7 \\
\hline \multirow{3}{*}{$\begin{array}{l}\text { 4. Orientation to the use of } \\
\text { power }\end{array}$} & Satisfied & 14 & 7.8 \\
\hline & Neutral & 36 & 20 \\
\hline & Dissatisfied & 130 & 72.2 \\
\hline
\end{tabular}

